\title{
The importance of physical culture and sports in student life
}

\section{Hafiz GAPPAROV ${ }^{1}$ Hikmatilla AKHMEDOV ${ }^{2}$}

Specialized branch Tashkent State University of Law

\begin{tabular}{l} 
ARTICLE INFO \\
\hline Article history: \\
Received September 2020 \\
Received in revised form \\
15 September 2020 \\
Accepted 15 October 2020 \\
Available online \\
30 October 2020 \\
\hline
\end{tabular}

Keywords:

Physical culture

Sports

Physical exercises

Health

Students

Physical training.

\begin{abstract}
The article discusses the concepts of physical culture and sports, the important task of which is strengthening and maintaining health, their importance in the life of students. It is also considered what role physical culture and sports play in student life, how it affects personality development and motivation for a healthy lifestyle of a student.

2181-1415/C) 2020 in Science LLC.

This is an open access article under the Attribution 4.0 International (CC BY 4.0) license (https://creativecommons.org/licenses/by/4.0/deed.ru)
\end{abstract}

\section{Талабаларнинг хаётида жисмоний маданият ва спортнинг ахамияти}

Калит суцзлар:

Жисмоний маданият

Спорт

Жисмоний машқлар

Соғлиқ

Талабалар

Жисмоний тайёргарлик

\section{АННОТАЦИЯ}

Мақолада жисмоний маданият ва спортнинг тушунчаси, уларнинг соғлиқни мустақкамлаш ва сақлашдаги мухим вазифаси хамда талабалар турмушидаги ахамияти кўриб чиқилган. Жисмоний маданият ва спорт билан шуғулланиш талабалар хаётида қандай рол ўйнайди, шахсни ривожланишига ва соғлом турмуш тарзда талабалар хаёт кечиришига қанчалик таъсир этишини.

\footnotetext{
${ }^{1}$ candidate of pedagogical sciences, Specialized branch Tashkent State University of Law, Tashkent, Uzbekistan

E-mail: gapparov70@mail.ru

2 candidate of pedagogical sciences, Specialized branch Tashkent State University of Law, Tashkent, Uzbekistan E-mail: hikmatilla616@g.mail.com
} 


\section{Важность физической культуры и спорта в студенческой ЖиЗни}

\author{
Ключевые слова: \\ Физическая культура \\ Спорт \\ Физические упражнения, \\ здоровье \\ Студенты \\ Физическая подготовка
}

\begin{abstract}
АННОТАЦИЯ
В статье рассмотрены понятия физической культуры и спорта, важной задачей которых является укрепление и сохранение здоровья, их значение в жизни студентов. Также рассмотрено, какую роль играет физическая культура и занятия спортом в студенческой жизни, как влияет на развитие личности и мотивацию к здоровому образу жизни студента.
\end{abstract}

Nowadays, students are required to work on themselves more effectively and enthusiastically, but the level of health of entrants has fallen sharply, the number of students with disabilities has increased and, as a result, exempted from physical education, so physical training and student health - the state's physical strength is an important ingredient.

Undoubtedly, it is necessary to cultivate in students the motivation and need for physical culture classes in adolescence, to increase physical culture literacy. Physical culture and sports provide not only a healthy lifestyle, but also a healthy lifestyle, that is, endless opportunities to apply all the strength and talent to life.

The importance of physical culture and sports stems from an understanding of its role in human life. The earlier consciousness comes, the sooner a person begins to live a healthy lifestyle.

The physical culture of students is an important part of higher education. Physical fitness should be considered as a quality factor influencing the personality of the future specialist, and the results will affect his professional qualifications.

Physical culture is a type of human and social culture. These are activities and socially significant outcomes that make people physically ready for life; it is, on the one hand, a peculiar development, and, on the other hand, the result of human activity, as well as a means and method of physical perfection.

Sport is a predominant form of physical culture, and the word is often used as a synonym for the concept of "physical culture". Sport can be seen as a system of physical culture outcomes, as the term refers to the pursuit of physical achievement based on norms and rules, training and competition.

With the help of physical culture and sports, a well-rounded person is formed. They use all the capabilities of the body to achieve high goals, as well as increase productivity, help to perform a large number of tasks during the working day. It absorbs a healthy lifestyle into a habit. In physical education classes, the tasks of strengthening and maintaining health are solved through active movement and exercise.

Another task of physical culture is its professional-practical orientation, ie the application of knowledge acquired in the course of professional activity, the formation of the order of work and rest, based on the characteristics of the specialty. It is no secret that physical culture and sports have a positive effect on how much mental activity increases. Mastering modern curricula is associated with great neuropsychological stress of students. 
It is extremely important that a student of a higher education institution has a high level of physical fitness to ensure mental and active functioning during the academic year.

The interrelationship of exercise and sport allows a person to form both an attractive appearance, as well as moral and volitional qualities, behavior and actions in society, which are determined by his inner world.

Physical culture and sports also perform an educational function, i.e. they help to develop and strengthen discipline, increase a sense of responsibility, and develop perseverance and aspiration.

Studies by leading scholars have shown that students who are active and regularly engaged in physical culture and sports have increased self-confidence and self-efficacy, formed a stable routine, boosted immunity, and therefore increased vital activity.

The study found that students involved in physical culture and sports developed a high sensitivity, stressfulness and emotional background to stressful situations, they were open and optimistic about cooperation.

Such students are characterized by a distinctive character as a leader: perseverance, perseverance, dedication, conscientiousness, purposefulness. They feel more confident at work than others, are creative, easily communicative, resourceful, and self-directed.

From the content of the article it can be concluded that maintaining and strengthening the health of students in higher education is based on the creation of a specially organized environment, which provides a solution to the main task - to strengthen students' understanding and importance of a healthy lifestyle, physical culture and sports.

\section{References:}

1. Мирзиёев Ш.М. Ёшларни тарбиялашдаги мухим 5 та ташаббус // 2019 йил 19 март кунидаги видеоселектор йиғилиши - www.uzdaily.uz/uz/post/5328

2. Жисмоний тарбия ва спортни янада ривожлантириш чора-тадбирлари тўғрисида. Ўзбекистон Республикаси Президентининг Пқ 3031-сонли қарори, 2017 йил, 3 -июн.

3. Ўзбекистон Республикасининг Қонуни “Жисмоний тарбия ва спорт тўғрисида (янги тахрири)" // https://www.lex.uz/acts/63106

4. Абдуллаев А., Хонкелдиев Ш.Х. Жисмоний тарбия назарияси ва усулияти. Дарслик. Т.: ЎзДЖТИ -2005.168 бет.

5. Koshbaxtiev I. A. Valeologiya asoslari. T.:TATU.- 2001.

6. Оболонский А.В., Егорычева Е.В., Чернышёва И.В., Шлемова М.В. Роль и значение физической культуры в жизни студенческой молодежи // Международный студенческий научны 